\title{
Heat tolerance in Brazilian sheep: Physiological and blood parameters
}

\author{
Concepta McManus • Giane Regina Paludo • \\ Helder Louvandini • Rosilene Gugel • \\ Luiz Cláudio Bastos Sasaki . \\ Samuel Rezende Paiva
}

Accepted: 13 March 2008 / Published online: 9 April 2008

(C) Springer Science + Business Media B.V. 2008

\begin{abstract}
Thirty Santa Ines adult, non-lactating, nonpregnant ewes, ten with a brown coat, ten black coated and ten white coated, as well as ten Bergamasca and ten of mixed breed were used to evaluate the effect of climate on physiological and blood parameters in sheep. Two sample collections were taken (6 AM and $2 \mathrm{PM}$ ) on six days. Sweating rate (SR), heart (HR) and breathing rates (BR), complete hemogram, rectal (RT) and skin temperatures (ST) were measured. Variance analyses were carried out using SAS ${ }^{\circledR}$. In general, there were significant differences between animals due to skin type, time and day of collection. White coated animals showed lower $\mathrm{HR}, \mathrm{BR}$ and RT, with afternoon parameters higher than morning. Correlations between HR, BR, RT, SR and ST were medium and positive. Correlations between physiological and blood traits were in general negative and medium. Packed Cell Volume (PCV), total plasma proteins, red blood cell count and hemoglobin concentration had high positive correlations between each
\end{abstract}

C. McManus $(\bowtie) \cdot$ G. R. Paludo $\cdot H$. Louvandini

R. Gugel - L. C. B. Sasaki

Faculdade de Agronomia e Medicina Veterinária,

Universidade de Brasília,

Brasília DF 70910-900, Brazil

e-mail: concepta@unb.br

\section{S. R. Paiva}

EMBRAPA Recursos Genéticos e Biotecnologia, PqEB,

Final W5 Norte,

Brasília DF, 70770-900, Brazil

e-mail: Samuel@cenragen.embrapa.br other. The first two autovectors explained $49 \%$ of variation between traits. White coated Santa Ines animals were shown to be better adapted to climatic conditions in Central Brazil and wool sheep more affected by heat.

Keywords Farm animal genetic resources . Hematological parameters - Ovis aries.

Physiological parameters $\cdot$ Stress $\cdot$ Temperature

\section{Introduction}

In recent years, sheep production in Brazil has grown rapidly. The central west region, although it has only $6.5 \%$ of the national herd, has increased effective herd size by 58\% between 1998 and 2007 (FNP Instituto 2007). Only the southern and northeastern regions of Brazil have larger herds and no other region has grown so much in herd size in recent years. Environmental and climatic conditions in the region are favorable for rearing sheep, as humidity is low and crop production is high. Nevertheless, animals may suffer in some situations as environmental temperatures may be above the comfort zone for sheep, which according to Baeta and Souza (1997) is between 20 and $30^{\circ} \mathrm{C}$, with the superior critical temperature being $34^{\circ} \mathrm{C}$.

Heat stress is considered a limiting factor for sheep production. Well adapted animals are characterized by maintenance, or minimum production loss, during the 
stress period, high reproductive efficiency, high disease resistance, longevity and low mortality rate. When the animal starts to suffer due to heat, food ingestion is reduced and metabolism slows, causing a hypo-function of the thyroid. This affects growth, reproductive efficiency, food conversion and milk production, leading to considerable economic losses (West 2003). A comprehensive review of this subject is given by Marai et al. (2007).

Several traits are used to evaluate physiological adaptation. There is no agreement between authors on which traits should be used but the most used include: respiratory frequency, heart rate, rectal and body surface temperatures as well cutaneous evaporation. Other indicators include: volume of air breathed, sweating rate, activity level, type of shade, ruminal movement frequency, hematological and other physiological traits (Silva 2000; Marai et al. 2007).

The type and colour of coat found is very important for heat resistance (Turner 1984; Finch et al. 1984). It is thought that animals with a dark coat, and therefore with greater absorption of thermal radiation, are more susceptible to heat stress than those with a light coloured coat (Silva 1998). In the semi-arid tropics heat gain is lower in animals with a dark coat (Robertshaw 1986). Despite this, according to Cunha et al. (2004), due to simply esthetics on the part of Santa Ines breeders, the black coated animals are more popular.

The present study aimed to analyze climatic effects on physiological parameters on Bergamasca (wool), Santa Inês (hair) and mixed breed (Santa Inês $\mathrm{x}$ Bergamasca) sheep in the Brazilian savannah.

\section{Materials and methods}

The experiment was carried out on the Água Limpa Farm of the University of Brasília, Federal District, Brazil. A total of fifty adult, non-lactating and nonpregnant ewes were used. Thirty of these were of the Santa Inês breed (10 with Brown coat, 10 black coated and 10 white coated), ten crossbred Santa Inês $\mathrm{x}$ Bergamasca and 10 purebred Bergamasca.

The animals were kept in a semi-intensive system, on Andropogon gayanus pasture, receiving concentrate supplement and mineral salt ad libitum. In the dry season (June to September), the animals were supplemented with corn silage and $300 \mathrm{~g}$ of concentrate/ animal/day.
Samples were collected on six separate days, in both the morning and afternoon. Between the two collections animals were kept in the sun with water $a d$ libitum. The following parameters were measured: sweating rate (SR), using the method proposed by Berman (1957), modified by Schleger and Turner (1965), respiratory rate (RR), heart rate (HR), rectal (RT) and skin temperature (ST). RR and HR were measured using a stethoscope. RT was measured with a digital thermometer introduced into the animal's rectum. ST was measured on a shaved area near the 12th vertebra of the animal using an infrared thermometer Raytek PhotoTemp ${ }^{\mathrm{TM}}$ MX6 ${ }^{\mathrm{TM}}$.

Blood was collected by venipuncture using vacutainer tubes with EDTA when the physiological traits were measured. The number of erythrocytes (Hem), leukocytes and the concentration of hemoglobin $(\mathrm{Hb})$ and were carried out in a semi-automatic cell counter $\left(\mathrm{CC} 550, \mathrm{Cellm}^{\mathrm{TM}}\right)$. The hematimetric parameters (Mean Corpuscular Volume - MCV and Mean Corpuscular Hemoglobin Concentration - MCHC) were determined by calculation.

Packed Cell Volume (PCV in \%) was determined using capillary tubes in microhematocrit centrifuge based on the technique described by Wintrobe (1976). The concentration of total plasma proteins (TPP in $\mathrm{g} /$ $100 \mathrm{~mL}$ ) was determined using a refractometer and the plasma retained in a capillary tube.

To characterize the thermal environment the following parameters were collected at 6:00 and 14:00: minimum and maximum temperatures, dry and wet bulb temperatures, relative air humidity and wind velocity. The Temperature-Humidity Index (THI) was calculated according to Marai et al. (2001) as: $\mathrm{THI}=\mathrm{db}^{\circ} \mathrm{C}-\left\{(0.31-0.31 \mathrm{RH})\left(\mathrm{db}^{\circ} \mathrm{C}-\right.\right.$ 14.4)\} where $\mathrm{db}^{\circ} \mathrm{C}$ is the dry bulb temperature $\left({ }^{\circ} \mathrm{C}\right)$ and $\mathrm{RH}$ is the relative humidity (RH\%)/100.

Physical skin factors were measured such as coat and skin reflectance using a wheatstone bridge (Silva 2000), skin thickness with an adipometer, number of hairs and percentage of sweat glands per $\mathrm{cm}^{2}$ after a histological analysis.

Statistical analyses were carried out using the Statistical Analysis System ${ }^{\circledR}$ package. The general linear model included day (six), time of day (morning and afternoon), group (five) and their interactions as fixed effects. Animal within group was fitted as a random effect. Skin and coat traits such as reflectance, thickness, number of hairs and sweat glands were 
included as covariables. Other analyses included correlations and principal components based on the parameters measured.

\section{Results}

Mean climatological data for the experimental days is shown in Table 1. These allowed for the calculation of the THI which was on average 19.05 in the morning and 24.04 in the afternoon.

Table 2 shows the summary of data analysis of the physiological parameters in question. Significant differences were found due to coat type, day and time of day. Few interactions were significant meaning that the groups reacted in the same manner independent of time of day. When coat type was included in the model, skin and coat reflectance values were not a significant source of variation on the traits examined. Skin thickness affected ST, PCV and TPP as did hair length. Skin thickness also affected HB and hair length affected SR, longer hairs causing higher SR. Area occupied by sweat glands affected PCV, Hem and HB. When coat type was removed from the model, the skin and coat traits were significant for almost all the traits examined.

Means for physiological parameters by animal group and time of day are in Table 3. Significant differences between morning and afternoon were noted for $H R, R R, R R, S T$ and SR, being lower earlier in the day when temperatures were lower and humidity higher. These differences can be attributed to climatic differences.

Correlations between physiological and blood traits are in Table 4. Correlations between HR, RR, RT, ST and TS were positive and medium. SR had a low negative correlation with blood traits. Correlations between physiological traits and blood parameters were in general medium and negative. PCV, TPP, HEM and HB concentration were correlated highly and positively between each other. Highest correlations for
MCV were with MCHC (-0.61) and PCV (0.40). SR had a correlation of $0.46 \mathrm{HCM}$.

The first two autovectors for the traits examined are in Fig. 1. The first autovector indicated that a decrease in ST, SR and RR was accompanied by an increase in HB and HEM levels as well as an increase in PCV and TPP. Here, longer hair and skin thickness was associated with higher respiratory rates and skin temperatures and lower skin and coat reflectance. RT and HR did not influence this autovector. The second autovector showed a subgroup of animals with high MCHC, RR, LEUK and RT but low MCV.

\section{Discussion}

Environmental temperature values in the afternoon were higher than the critical temperature of 24 to $27^{\circ} \mathrm{C}$, for most species (Fuquay 1981). The TemperatureHumidity Index (THI) (LPHSI 1990; Marai et al. 2001) for these data indicate that in the morning the animals were not experiencing heat stress $(\mathrm{THI}=19.05)$ while in the afternoon, heat stress was classified as severe $(\mathrm{THI}=24.04)$.

The increase in RR in the afternoon is in agreement with that observed by Brasil et al. (2000), working with goats in thermo neutral conditions as well as those under thermal stress found similar results for RR. The increase in HR in the afternoon was also found by Cézar et al. (2004) and Santos et al. (2003) working with sheep in the northeast of Brazil, who found respectively, a rate of $105.67 \mathrm{mov} / \mathrm{min}$ and $126.4 \mathrm{mov} / \mathrm{min}$ in the morning and $115.30 \mathrm{mov} / \mathrm{min}$ and $133.2 \mathrm{mov} / \mathrm{min}$, in the afternoon. Lowest means for the traits observed in this study coincided with lowest environmental temperatures during the experimental period.

Within the different groups, the Bergamasca animals showed highest means for RT, ST, SR and especially RR. According to Silva (2000), the protective coat offered by the wool fleece considerably reduces

Table 1 Mean climate data for experimental days testing heat tolerance in sheep

\begin{tabular}{lllllll}
\hline & $\begin{array}{l}\text { Minimum } \\
\text { temperature } \\
\left({ }^{\circ} \mathrm{C}\right)\end{array}$ & $\begin{array}{l}\text { Maximum } \\
\text { temperature } \\
\left({ }^{\circ} \mathrm{C}\right)\end{array}$ & $\begin{array}{l}\text { Relative } \\
\text { humidity } \\
(\%)\end{array}$ & $\begin{array}{l}\text { Dry bulb } \\
\text { temperature } \\
\left({ }^{\circ} \mathrm{C}\right)\end{array}$ & $\begin{array}{l}\text { Wet bulb } \\
\text { temperature } \\
\left({ }^{\circ} \mathrm{C}\right)\end{array}$ \\
\hline $6: 00 \mathrm{~h}$ & $17.28 \pm 1.21$ & $23.60 \pm 2.43$ & $89.7 \pm 2.5$ & $19.20 \pm 1.60$ & $\begin{array}{l}\text { Wind velocity } \\
(\mathrm{m} / \mathrm{s})\end{array}$ \\
$14: 00 \mathrm{~h}$ & $19.46 \pm 2.42$ & $27.32 \pm 2.72$ & $70.3 \pm 5.6$ & $25.06 \pm 3.21$ & $19.71 \pm 3.12$ & $2.43 \pm 0.06$ \\
\hline
\end{tabular}


Table 2 Summary of variance analysis for physiological traits linked to heat tolerance in Santa Inês (Brown, Black and White coat), woolen crossbreds and Bergamasca sheep in Brazil

\begin{tabular}{|c|c|c|c|c|c|c|c|c|c|c|c|c|}
\hline & HR & $\mathrm{RR}$ & RT & ST & SR & PCV & TPP & HEM & $\mathrm{HB}$ & LEUK & $\mathrm{MCV}$ & $\mathrm{MCHC}$ \\
\hline Coat & * & $* * *$ & $* * *$ & $* * *$ & $* * *$ & $* * *$ & $* * *$ & $* * *$ & $* * *$ & ns & * & $*$ \\
\hline Day & ns & $* * *$ & ns & $* * *$ & $* * *$ & $* * *$ & $*$ & $* * *$ & $* * *$ & ns & ns & $*$ \\
\hline Coat $*$ Day & ns & $* * *$ & ns & $* * *$ & $* * *$ & ns & $* * *$ & ns & ns & ns & ns & ns \\
\hline Time & $* * *$ & $* * *$ & $* * *$ & $* * *$ & $* *$ & ns & ns & $\mathrm{ns}$ & ns & $*$ & ns & ns \\
\hline Coat $*$ Time & ns & ns & ns & ns & ns & ns & ns & ns & ns & ns & ns & ns \\
\hline Day $*$ Time & ns & $* * *$ & ns & $* * *$ & ns & ns & ns & ns & ns & ns & ns & ns \\
\hline Coat $*$ Time $*$ Day & ns & $\mathrm{ns}$ & ns & ns & ns & ns & ns & ns & ns & $\mathrm{ns}$ & ns & $* * *$ \\
\hline Animal (Coat type) & $* * *$ & $* * *$ & $* * *$ & $* * *$ & $* * *$ & $* * *$ & $* * *$ & $* * *$ & $* * *$ & $* * *$ & $* * *$ & $* * *$ \\
\hline $\mathrm{TS}$ & ns & ns & ns & $*$ & $* * *$ & $*$ & ns & $*$ & ns & ns & ns & ns \\
\hline CRef & ns & ns & ns & ns & ns & ns & ns & ns & ns & ns & ns & ns \\
\hline SRef & ns & ns & ns & ns & ns & ns & ns & ns & ns & ns & ns & ns \\
\hline Len & ns & $* * *$ & ns & $\mathrm{P}<.1$ & $*$ & $*$ & $*$ & ns & ns & ns & ns & ns \\
\hline Area & ns & ns & ns & ns & ns & $* *$ & ns & $*$ & $* * *$ & ns & ns & ns \\
\hline$R^{2}$ & 0.31 & 0.66 & 0.74 & 0.82 & 0.51 & 0.58 & 0.49 & 0.54 & 0.54 & 0.37 & 0.39 & 0.56 \\
\hline $\mathrm{CV}$ & 17.67 & 29.04 & 1.15 & 2.48 & 48.28 & 17.09 & 10.72 & 21.67 & 17.07 & 32.77 & 20.53 & 15.05 \\
\hline
\end{tabular}

*** $\mathrm{P}<0.001 ; * * \mathrm{P}<0.01 ; * \mathrm{P}<0.05$, ns- not significant, CV - coefficient of variation, $\mathrm{R}^{2}$ - coefficient of determination, HR- Heart rate, RR- Respiratory rate, TR- Rectal temperature, ST- Skin temperature; SR-Sweating rate, PCV(\%) - packed cell volume, TPP- Total plasma protein $(\mathrm{g} / 100 \mathrm{~mL})$, LEUK - Leukocytes $\left(\mathrm{x} 10^{3} / \mathrm{mm}^{3}\right)$, HEM - Red blood cells $\left(\mathrm{x} 10^{6} / \mathrm{mm}^{3}\right)$, HB - Hemoglobin $(\mathrm{g} / 100 \mathrm{~mL})$, MCV - Mean Corpuscular Volume (fl), MCHC (\%) -Mean Corpuscular Hemoglobin Concentration; Cref - Coat Reflectance, SREf Skin Reflectance, Area - Area of Sweat glands (\%), Len - Hair length (mm), TS - Thickness of skin (mm)

evaporation by sweating and therefore evaporation through respiration is very important for thermoregulation in these animals. Low evaporation did not occur in wool animals as proposed by Silva (2000), as those with a fleece also showed highest sweating rates (Crosses and Bergamasca). The Santa Inês had lower means for RT and SR than wool animals, suggesting that these are more resistant to higher environmental temperatures. Differences were also noted between animals of different coat colour within the Santa Inês group, those with a white coat having indices indicating better tolerance to heat stress. This is in agreement with Shearer (1990) who noted that animals with lighter coat colours reflected more light and absorbed between 40 and 50\% less radiation than those with dark coats.

Table 3 Means for physiological and blood traits in Santa Ines (Brown, Black and White coats), crossbred woolen and Bergamasca sheep

\begin{tabular}{|c|c|c|c|c|c|c|c|c|c|c|c|c|}
\hline & HR & RR & RT & ST & SR & PCV & ТPP & HEM & $\mathrm{HB}$ & LEUK & $\mathrm{MCV}$ & $\mathrm{MCHC}$ \\
\hline Brown & $104.57^{\mathrm{b}}$ & $41.21^{\mathrm{c}}$ & $38.70^{\mathrm{b}}$ & $36.25^{\mathrm{bc}}$ & $187.51^{\mathrm{ab}}$ & $30.00^{\mathrm{b}}$ & $7.06^{\mathrm{b}}$ & $10.46^{\mathrm{b}}$ & $9.25^{\mathrm{a}}$ & 12.28 & 29.57 & $12.28^{\mathrm{ab}}$ \\
\hline Black & $100.34^{\mathrm{ab}}$ & $39.66^{\mathrm{c}}$ & $38.74^{\mathrm{b}}$ & $36.10^{\mathrm{c}}$ & $148.15^{\mathrm{b}}$ & $29.52^{\mathrm{b}}$ & $7.10^{\mathrm{b}}$ & $10.87^{\mathrm{b}}$ & $9.47^{\mathrm{a}}$ & 13.36 & 30.61 & $13.36^{\mathrm{ab}}$ \\
\hline White & $94.86^{\mathrm{a}}$ & $34.38^{\mathrm{b}}$ & $38.65^{\mathrm{b}}$ & $35.99^{c}$ & $150.53^{\mathrm{b}}$ & $29.40^{\mathrm{b}}$ & $6.92^{\mathrm{b}}$ & $10.70^{\mathrm{b}}$ & $9.54^{\mathrm{a}}$ & 14.59 & 32.07 & $14.59^{\mathrm{ab}}$ \\
\hline Cross & $87.60^{\mathrm{a}}$ & $39.65^{\mathrm{c}}$ & $39.04^{\mathrm{a}}$ & $36.78^{\mathrm{ab}}$ & $240.37^{\mathrm{a}}$ & $31.32^{\mathrm{b}}$ & $6.87^{\mathrm{b}}$ & $11.64^{\mathrm{b}}$ & $9.87^{\mathrm{a}}$ & 13.80 & 30.37 & $13.80^{\mathrm{b}}$ \\
\hline Bergamasca & $101.34^{\mathrm{b}}$ & $54.94^{\mathrm{a}}$ & $39.12^{\mathrm{a}}$ & $37.41^{\mathrm{a}}$ & $248.60^{\mathrm{a}}$ & $24.26^{\mathrm{a}}$ & $5.96^{\mathrm{a}}$ & $8.47^{\mathrm{a}}$ & $8.00^{\mathrm{b}}$ & 12.31 & 33.25 & $12.31^{\mathrm{a}}$ \\
\hline Morning & $92.82^{\mathrm{a}}$ & $35.66^{\mathrm{a}}$ & $38.25^{\mathrm{a}}$ & $35.18^{\mathrm{a}}$ & $154.92^{\mathrm{a}}$ & 29.13 & 6.84 & 10.54 & 9.12 & 11.77 & 31.17 & 11.77 \\
\hline Afternoon & $104.63^{b}$ & $49.85^{\mathrm{b}}$ & $39.44^{\mathrm{b}}$ & $37.85^{\mathrm{b}}$ & $231.78^{\mathrm{b}}$ & 28.31 & 6.70 & 10.04 & 9.16 & 14.77 & 31.34 & 14.77 \\
\hline Reference Values & $70-80 *$ & $\begin{array}{c}20- \\
34 *\end{array}$ & $\begin{array}{l}38.3- \\
39.9 *\end{array}$ & & & $\begin{array}{l}27- \\
45^{* *}\end{array}$ & $\begin{array}{l}6- \\
7.5 * *\end{array}$ & $\begin{array}{l}9- \\
15^{* *}\end{array}$ & $\begin{array}{l}9- \\
15^{* *}\end{array}$ & $\begin{array}{l}4- \\
12 * *\end{array}$ & $\begin{array}{l}31- \\
34 * *\end{array}$ & $\begin{array}{l}8- \\
12 * *\end{array}$ \\
\hline
\end{tabular}

HR- Heart rate, RR- Respiratory rate, TR- Rectal temperature, ST- Skin temperature; SR-Sweating rate, PCV(\%) - packed cell volume, TPPTotal plasma protein $(\mathrm{g} / 100 \mathrm{~mL})$, LEUK - Leukocytes $\left(\mathrm{x} 10^{3} / \mathrm{mm}^{3}\right)$, HEM - Red blood cells $\left(\mathrm{x} 10^{6} / \mathrm{mm}^{3}\right), \mathrm{HB}-\mathrm{Hemoglobin}(\mathrm{g} / 100 \mathrm{~mL})$, MCV - Mean Corpuscular Volume (fl), MCHC (\%) -Mean Corpuscular Hemoglobin Concentration; Means by group or time of day followed by different letters in the same column are significantly different using the Tukey test $(\mathrm{P}<0.05)$

* Swenson and Reece (2006), ** Jain (1993), *** Blood et al. (1983) 
Table 4 Correlations between physiological and blood traits linked to heat tolerance in Santa Ines, crossbred and Bergamasca sheep

\begin{tabular}{|c|c|c|c|c|c|c|c|c|c|c|c|}
\hline & HR & $\mathrm{RR}$ & $\mathrm{RT}$ & $\mathrm{ST}$ & SR & PCV & ТPP & HEM & HB & LEUK & $\mathrm{MCV}$ \\
\hline $\mathrm{RR}$ & 0.30 & & & & & & & & & & \\
\hline $\mathrm{RT}$ & 0.30 & 0.43 & & & & & & & & & \\
\hline $\mathrm{ST}$ & 0.29 & 0.51 & 0.75 & & & & & & & & \\
\hline SR & 0.06 & 0.48 & 0.40 & 0.49 & & & & & & & \\
\hline PCV & -0.16 & -0.29 & -0.16 & -0.40 & -0.12 & & & & & & \\
\hline ТPP & -0.17 & -0.37 & -0.19 & -0.40 & -0.19 & 0.67 & & & & & \\
\hline HEM & -0.15 & -0.34 & -0.20 & -0.32 & -0.12 & 0.80 & 0.60 & & & & \\
\hline $\mathrm{HB}$ & -0.12 & -0.23 & -0.10 & -0.27 & -0.01 & 0.81 & 0.60 & 0.89 & & & \\
\hline LEUK & 0.08 & 0.12 & 0.28 & 0.14 & 0.16 & 0.15 & 0.17 & 0.21 & 0.26 & & \\
\hline $\mathrm{MCV}$ & -0.01 & -0.18 & -0.11 & 0.00 & 0.10 & 0.13 & 0.07 & -0.37 & -0.32 & -0.16 & \\
\hline $\mathrm{MCHC}$ & -0.03 & 0.19 & 0.08 & 0.16 & -0.04 & -0.40 & -0.28 & 0.04 & 0.14 & 0.17 & -0.61 \\
\hline
\end{tabular}

HR- Heart rate, RR- Respiratory rate, ST- Rectal temperature, TP- Skin temperature; SR-Sweating rate, PCV(\%) - packed cell volume, TPP- Total plasma protein $(\mathrm{g} / 100 \mathrm{~mL})$, LEUK - Leukocytes $\left(\mathrm{x} 10^{3} / \mathrm{mm}^{3}\right)$, HEM - Red blood cells $\left(\mathrm{x} 10^{6} / \mathrm{mm}^{3}\right)$, HB Hemoglobin (g/100 mL), MCV - Mean Corpuscular Volume (fl), HCM (pg), MCHC (\%) -Mean Corpuscular Hemoglobin Concentration.

The results shown here have implications for the hair sheep industry in Brazil. The Santa Inês breed is the most numerous, especially in the Northeast region where hair sheep are predominant and environmental temperatures high. In recent years, selection within the breed has been given to animals with black coats, while other coat colours have practically disappeared in some regions. According to Marai et al. (2001) the morphological characteristics preferred in hot climate breeds should include a large skin area to live weight ratio, shielded eyes, pigmented skin and eye lids (to

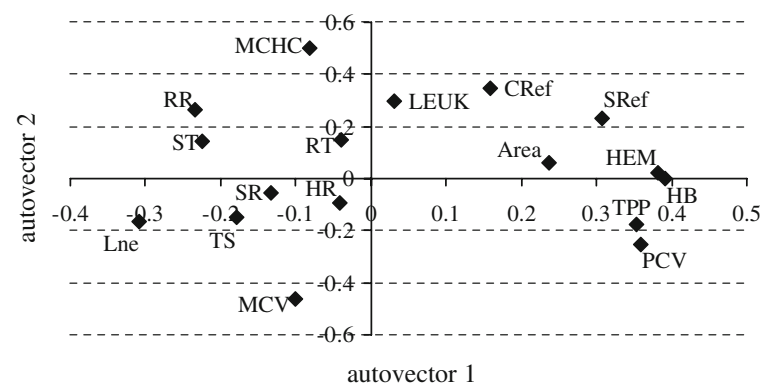

Fig. 1 First two autovectors for physiological and blood traits in sheep in the Federal District, Brazil. HR- Heart rate, RR- Respiratory rate, RT- Rectal temperature, ST- Skin temperature; SR-Sweating rate, PCV $(\%)$ - packed cell volume, TPP- Total plasma protein $(\mathrm{g} / 100 \mathrm{~mL})$, LEUK - Leukocytes $\left(\times 10^{3} / \mathrm{mm}^{3}\right)$, HEM - Red blood cells $\left(\times 10^{6} / \mathrm{mm}^{3}\right)$, HB - Hemoglobin $(\mathrm{g} / 100 \mathrm{~mL}), \mathrm{MCV}$ - Mean Corpuscular Volume (fl), MCHC (\%) -Mean Corpuscular Hemoglobin Concentration, CRef - Coat Reflectance, SRef - Skin Reflectance, Area - Area of Sweat glands (\%), Len - Hair length $(\mathrm{mm}), \mathrm{TS}-$ Thickness of skin (mm) lessen susceptibility to eye cancer) and a light coloured or white body cover.

All group means for RT were below upper normal limits, in agreement with Andersson and Jónasson (2006) who showed that in sheep the RT begins to rise above normal rates when environmental temperature reaches $32^{\circ} \mathrm{C}$. This temperature was not reached in this experiment. It should be noted that small alterations in rectal temperature may be important in animals under thermal stress. According to McDowell (1972), an increase of $1^{\circ} \mathrm{C}$ or less in the RT is enough to reduce performance in most domestic animal species.

Silvanikove (2000) classified the severity of heat stress due to respiratory rate, where a frequency of 40-60 mov/min characterized low stress, $60-80 \mathrm{mov} /$ min medium - high stress, $80-120 \mathrm{mov} / \mathrm{min}$ high stress and above 200 would be severe stress in sheep. The animals here were therefore under low heat stress by this classification. According to Andersson and Jónasson (2006), sheep start to present open mouth polypneia when $\mathrm{RR}$ is above $41^{\circ} \mathrm{C}$, which was not observed in this experiment.

For blood traits no specific pattern for the different groups or time of day was observed. The number of leukocytes was higher in the afternoon, and this was above reference values for this species, characterizing leukocytosis. This is in agreement with Paludo et al. (2002) who found an increase in leukocyte number after exercise and exposure to the sun in several horse breeds. These increases in leukocyte number may be 
considered physiological as they are due to an increase in blood pressure and heart rate. This is due to the action of epinephrine and cortisone, liberated in situations of stress, fear, excitement or vigorous exercise (Coles 1984; Jain 1993). According to Johnson et al. (1991) and Elvinger et al. (1992), thermal stress may cause dilution, concentration or have no effect on volume of blood plasma. In this experiment discrete individual increases in TPP and PCV were observed between morning and afternoon collections. The effect of heat stress on plasmatic volume was therefore very small, and the sweating rate was not sufficiently high to cause dehydration.

Considering correlations observed between physiological and blood traits, a positive correlation between RR and RT was also observed by McManus and Miranda (1997) and Starling et al. (2002) for sheep in Brazil, as well as between these traits and ST. According to Starling et al. (2002) the positive correlation between $\mathrm{RR}$ and $\mathrm{RT}$ indicates that the respiratory mechanism was very important for thermolysis and maintenance of homeothermia in the animals, to avoid an increase in body temperature. The positive correlations also suggest that the animals absorb environmental heat and the following rise in skin temperature activates homeothermic mechanisms causing increases in RR, since sweating and polypneia are important heat regulatory processes in this species (Andersson and Jónasson 2006).

The first autovector analysis indicated that an increase in HCM, ST, RT and RR was accompanied by an increase in HB and HEM levels as expected. PCV and TPP were also low and SR did not influence this autovector. This may be explained by the fact that most animals were not in stress and were not sweating profusely. In fact, all animals with TR above 39.9 were Bergamasca or wool crossbreds, in the afternoon period. This is in agreement with Silva and Starling (2003) who investigated cutaneous and respiratory evaporation in wool sheep.

According to the second autovector, animals could be classified as a subgroup of animals with high MCHC, RR, SR, LEUK and RT but low MCV. Quesada et al. (2001) observed that there were sheep with high TR and RR which were not accompanied by an increased heart rate, showing a possible increased tolerance to adverse climatic conditions. When RT increases due to a continued action of environmental effects, this influences heart rate and respiratory rate due to activation of control mechanisms for the animal to reestablish equilibrium in its vital functions.

\section{Conclusion}

The increase in respiratory frequency observed may be considered the main mechanism for control of homeothermia under the imposed environmental conditions, accompanied by other mechanisms such as increase in heart rate. The leukocytosis due to demarginalization of cells from the marginal compartment due to increase in peripheral blood flow was the only variation in blood parameters observed, indicating that the animals didn't have a sweating profuse enough to cause blood concentration. The hair sheep with white coat were shown to be better adapted to the conditions imposed, while Bergamasca were least well adapted.

Acknowledgements To CNPq for research scholarships and FINATEC for financial aid as well as the students who helped in blood collection.

\section{References}

Andersson, B.E. and Jónasson, H., 2006. Regulação da temperatura e fisiologia ambiental. In: M.J. Swenson and W.O. Reece (eds), Dukes - Fisiologia dos Animais Domésticos, 12th ed, (Guanabara Koogan S.A., Rio de Janeiro), 805-813

Baeta, F.C. and Souza, C.F., 1997. Ambiência em edificações rurais: conforto animal, (unpublished $\mathrm{PhD}$ thesis, Universidade Federal de Viçosa)

Barbosa, O.R. and Silva, R.G., 1995. Índice de conforto térmico para ovinos, Boletim Indústria animal, 52, 29-35

Berman, A., 1957. Influence of some factors on the relative evaporative rate from the skin of cattle, Nature, 179, 1256

Blood, D.C., Henderson, J.A. and Radostits, O.M., 1983. Clinica Veterinaria, $5^{\mathrm{a}}$ Ed. (Editora Guanabara Koogan S. A., Rio de Janeiro)

Brasil, L.H.A., Wechesler, F.S., Baccari Júnior, F., Gonçalves, H.C. and Bonassi, I.A., 2000. Efeitos do estressee térmico sobre a produção, composição química do leite e respostas termorreguladoras de cabras da raça Alpina, Revista Brasileira Zootecnia, 29, 1632-1641

Cézar, M.F., Souza, B.B., Souza, W.H., Pimenta Filho, E.C. and Tavares, G.P., 2004. Avaliação de Parâmetros Fisiológicos de Ovinos Dorper, Santa Inês e seus Mestiços frente às Condições Climáticas do Trópico Semi-Árido Nordestino, Ciência e Agrotecnologia, 28, 614-620

Coles, E.H., 1984. Patologia clínica veterinária, 3.ed. (Manole, São Paulo)

Cunha, E.A., Bueno, M.S., and Santos, L.E., 2004. Santa Inês: a produção intensiva de carne, Revista O Berro, 63, 6-10 
Elvinger, F., Natzke, R.P. and Eggert, R.G., 1992. Interactions of heat stress and bovine somatotropin affecting physiology and immunology of lactating cows, Journal Dairy Science, 75, 449-462

Finch, V.A., Bennett, I.L. and Holmes, C.R., 1984. Coat colour in cattle: effect on thermal balance, behavior and growth, and relationship with coat type, Journal Agriculture Science, 102, 141-147

FNP Instituto, 2007. Anualpec 2007, (Agra FNP Pesquisas Ltda, São Paulo)

Fuquay, J.W., 1981. Heat stress as it affects animal production, Journal Animal Science, 52, 164-182

Jain, N.C., 1993. Essentials of Veterinary Hematology, (Editora Lea e Febiger, Philadelphia)

Johnson, P.J., Goetz, T.E., Foreman, J.H., Vogel, R.S., Hoffman, W.E. and Baker, G.J., 1991. Effect of whole-body gluteal muscle potassium concentration of healthy, adult horses, American Journal Veterinary Research, 52, 1676-1683

LPHSI, 1990. LPHSI, Livestock and poultry heat stress indices, Agriculture Engineering Technology Guide, (Clemson University, Clemson, SC)

Marai, I.F.M., Ayyat, M.S. and Abd El-Monem, U.M., 2001. Growth performance and reproductive traits at first parity of New Zealand White female rabbits as affected by heat stress and its alleviation under Egyptian conditions, Tropical Animal Health Production, 33, 457-462

Marai, I.F.M., El-Darawany, A.A., Fadiel, A. and Abdel-Hafez, M.A.M., 2007. Physiological traits as affected by heat stress in sheep-A review, Small Ruminant Research, 71, $1-12$

McDowell, R.G., 1972. Improvement of livestock production in warm climates, (Freeman, San Francisco)

McManus, C. and Miranda, R.M., 1997. Comparação das raças de ovinos Santa Inês e Bergamácia no Distrito Federal, Revista Brasileira Zootecnia, 26, 627-636

Paludo, G.R., McManus, C., Melo, R.Q., Cordoso, A.G., Melo, F.P.S., Moreira, M. and Fuck, B., 2002. Effect of heat stress and exercise on physiological parameters of horses of the Brazilian army, Revista Brasileira Zootecnia, 31, $1130-1142$

Quesada, M., McManus, C. and Couto, F.A.D., 2001. Heat tolerance of two hair sheep breeds in the Federal District, Brazil, Revista Brasileira Zootecnia, 30, 1021-1026
Robertshaw, D., 1986. Physical and physiological principles of adaptation of animals to the tropics, Proceedings of the $1 \mathrm{st}$ Simposio International de bioclimatologia animal nos trópicos: pequenos e grandes ruminantes, Fortaleza, 87-94

Santos, J.R.S., Souza, B.B., Souza, W.H., Cezar, M.F. and Tavares, G.P., 2003. Avaliação da adaptabilidade de ovinos da raça Santa Inês, Morada Nova e mestiços de Dorper, no semi-árido, Proceedings of the 40th Reunião Anual da Sociedade Brasileira de Zootecnia, Santa Maria, RS, $1-5$

Schleger, A.V. and Turner, H.G., 1965. Sweating rates of cattle in the field and their reaction to diurnal and seasonal changes, Australian Journal Agriculture Research, 16, 92-106

Shearer, J.K., 1990. Effects of high environmental temperature on production, reproduction, and health of dairy cattle, Agriculture Practice, 11, 5-17

Silva, R.G., 1998. Estimação do balanço térmico por radiação em vacas holandesas a sol e a sombra, Proceedings of the 2nd congresso brasileiro de biometeorologia, Goiania, $118-128$

Silva, R.G., 2000. Introdução à bioclimatologia animal, (Nobel, São Paulo)

Silva, R.G. and Starling, J.M.C., 2003. Evaporação Cutânea e Respiratória em ovinos sob altas temperaturas ambientes, Revista Brasileira Zootecnia, 32, 1956-1961

Silvanikove, N., 2000. Effects of heat stress on the welfare of extensively managed domestic ruminants, Livestock Production Science, 67, 1-18

Starling, J.M.C., Silva, R.G., Cerón-Muñoz, M., Barbosa, G.S. S.C. and Costa, M.J.R.P., 2002. Analysis of some physiological variables for the evaluation of the degree of adaptation in sheep submitted to heat stress, Revista Brasileira de Zootecnia, 32, 2070-2077

Swenson, M.J. and Reece, W.O., 2006. Dukes - Fisiologia dos Animais Domésticos, 12 ed, (Guanabara Koogan S.A., Rio de Janeiro)

Turner, H.G., 1984. Variation in rectal temperature of cattle in a tropical environment and its relation to growth rate, Animal Production, 38, 417-427

West, J.W., 2003. Effects of heat stress on production in dairy cattle, Journal Dairy Science, 86, 2131-2144

Wintrobe, M.M., 1976. Clinical Hematology, (Lea and Febiger, Philadelphia) 